\title{
Právo rozhodné pre medzinárodnú licenčnú zmluvu - medzery a limity aplikácie Nariadenia Rím I
}

\section{Law Applicable on International Licence Agreements-gaps and Limits of Application of Rome I Regulation}

\author{
Mária Pastorková*
}

\begin{abstract}
Abstrakt
Významnost' medżinárodných licenčných zmlúv je neodškriepitelná, avšak špeciálne kolizne pravidlo zamerané na licenčné żmluvy neexistuje. V rámci EU sa na urǔenie roz̧bodnébo práva v sporoch vyplývajúcich z licenčných żmlúv poư̌ije Nariadenie Rím I. Vedecké skúmania často končia práve na analýze Nariadenia Rím I, cielom tohto článku je ist' d'alej za jeho branice. Autorka skúma limity použitia Nariadenia Rím I a hl'adá situácie, kedy a či vôbec sa v prípade sporov z. medzinárodnej licencie použije Zákon o medzinárodnom práve súkromnom alebo bilaterálna żmluva. Najdôle řitejšiu úlobu v danom skúmani predstavije kvalifikácia. Kvalifikácia urǔuje, či sa jedná o spor vyplývajúci zo żmluvnébo alebo mimozmluvnébo záväzku a vo výsledku umo:̌ni nájdenie relevantnébo právneho prameña.
\end{abstract}

\section{Klíčová slova}

Licenčná zmluva; duševné vlastníctvo; Nariadenie Rim I; ZMPS; kvalifikácia; lex loci protectionis; jednostranné právne jednanie.

\begin{abstract}
The importance of the international licence agreements is undisputable. However, there still doesn't exist the special conflict of laws rule for them. Thus, the Rome I Regulation is used also for the purpose of determining applicable law in the disputes evolved from licence agreements within EU. All analyses stop on examination of regulation but this contribution aims to go further. The author examines the limits of its application and finds the situations, when would be (if ever) Czech Private International Act or bilateral convention applicable. The most important part of examination is the understatement of the qualification. Qualification determines the contractual or non-contractual core of the dispute, the connection of the aspects of dispute and in the end would help to find the relevant legal source.
\end{abstract}

Keywords

Licence Agreement, Intellectual Property, Rome I Regulation, Czech PILA, Qualification, Lex Loci Protectionis, Unilateral Legal Act.

\footnotetext{
Mgr. Mária Pastorková, doktorandka, Katedra mezinárodního a evropského práva, Právnická fakulta Masarykovy univerzity, Brno / Ph.D. student, Department of International and European Law, Faculty of Law, Masaryk University, Brno, Czech Republic / E-mail: 325623@mail.muni.cz
} 


\section{Úvod $^{1}$}

Medzinárodná licenčná zmluva už dlhodobo ukazuje svoju významnost' na medzinárodnom poli práva duševného vlastníctva. Svoju dôležitost' vždy predstavovala ako zmluvný nástroj podporujúci a ovplyvňujúci medzinárodný obchod. ${ }^{2}$ Nie je tomu inak ani v dnešnej dobe, ked’že sa stáva možným zakončením odborných výskumov a inovácii. ${ }^{3}$ Z pohl'adu akademického skúmania je potrebné riešit' otázky, ktoré sa často neobjavujú, ale existujú a je potrebné $\mathrm{k}$ nim zaujat’ jasné stanovisko. Hladanie rozhodného práva pre medzinárodnú licenčnú zmluvu z pohl’adu národného, konkrétne českého súdu, samo o sebe predstavuje takúto otázku. Je tomu tak primárne z dôvodu neexistencie špeciálneho kolízneho pravidla $\mathrm{v}$ európskom meradle pre zmluvy súvisiace s duševným vlastníctvom, nie to ešte konkrétne pre licenčnú zmluvu. ${ }^{4}$ Všeobecne sa prijíma názor o aplikácii Nariadenia Európskeho Parlamentu a Rady (ES) č. 593/2008 zo 17. júna 2008 o rozhodnom práve pre zmluvné záväzky (d’alej len „Nariadenie Rím I“) ${ }^{5}$ a skúma sa jeho dopad na licenčnú zmluvu. ${ }^{6}$

Skúmaniu ustanovení Nariadenia Rím I sa článok venovat' nebude, ked’že inovatívnejším skúmaním je snaha pozriet' sa za hranice Nariadenia Rím I. Otvára sa otázka, čo sa stane v prípade, kedy sa Nariadenie Rím I nepoužije. Je to pohl’ad pomerne nezvyčajný, ked’že pri analýze medzinárodnej kolíznej normy sa často končí pri Nariadení Rím I. Celý proces skúmania výrazne ovplyvňuje kvalifikácia licencie. Článok prekračuje hranice bežného nazerania na medzinárodnú licenčnú zmluvu optikou Nariadenia Rím I a zameriava sa na jeho limity, ktoré môžu mat' vel'ký dopad na praktické aj teoretické vnímanie medzinárodnej licenčnej zmluvy a zároveň poukazuje na praktické príklady. Dôležitost' skúmania tejto problematiky sa prejavuje v neexistencii ucelenej judikatúry venujúcej sa určovaniu rozhodného práva pre spory vyplývajúce z medzinárodnej licenčnej zmluvy.

1 Článok vznikol v rámci projeku Mezinárodní licenční smlouva-kolizní otázky (MUNI/A/1307/2015).

2 HNÍZDO, Miroslav. Licence v praxi. Praha: Československá obchodní a průmyslová komora, 1982, s. 6-7; BORSKÝ, Emil. Co je tréba védět o licenční smlouvě. Praha: Československá obchodní komora, 1968, s. 5.

3 ČADA, Karel. Strategie primyslového vlastnictví. Praha: Metropolitan University Prague Press, 2014, s. 31; TELEC, Ivo. Prébled práva duševního vlastnictví. 1, Lidskoprávní qáklady, licenćní smlouva. 2., upr. vyd. Brno: Doplněk, 2002, s. 104-105.

4 MANKOWSKI, Petr. Contrats relating to the Intellectual or Industrial Property rights under the Rome I regulation. In: LEIBLE Stefan, OHLY, Ansgar (eds.). Intellectual Property and Private International Law. Tübingen: Mohr Siebeck, 2009, s. 31-33.

5 Nariadenie Európskeho Parlamentu a Rady (ES) č. 593/2008 zo 17. júna 2008 o rozhodnom práve pre zmluvné záväzky. In: EUR-Lex [právny informačný systém]. Úrad pre vydávanie publikácií Európskej únie [cit. 20. 8. 2016].

6 MANKOWSKI, op. cit., s. 31-78; DE MIGUEL ASENSIO, A Pedro. The law governing international intellectual property licensing agreements (conflict of laws analysis). In: WERRA, de Jacques (ed.). Research handbook on intellectual property licensing. Cheltenham, UK: Edward Elgar, 2013, s. 321-331. 
Prvá situácia, kedy sa nepoužije Nariadenie Rím I, nastáva v prípade prednosti iných prameňov, konkrétne medzinárodných zmlúv. ${ }^{7}$ Druhou situáciou je existencia medzier Nariadenia Rím I, ${ }^{8}$ ktoré vedú k použitiu Zákona o medzinárodnom práve súkromnom (d’alej len „ZMPS“) ${ }^{9}$ alebo Nariadenie Európskeho Parlamentu a Rady (ES) č. 864/2007 z 11. júla 2007 o rozhodnom práve pre mimozmluvné záväzky (d’alej len „Nariadenie Rím II"). ${ }^{10}$ Nasledujúce kapitoly sú zamerané na skúmanie uvedených oblastí a zodpovedanie si otázky, v akých sporoch vyplývajúcich z licenčných zmlúv sa nepoužije Nariadenie Rím I.

\section{Medzinárodná licenčná zmluva pohl’adom českého súdu}

Spory vyplývajúce z medzinárodných licenčných zmlúv pred českými súdmi môžu vyvolat' viacero otázok. Prvou je jednoznačne samotná existencia medzinárodného prvku. Medzinárodný prvok v licenčnom zmluvnom vzt'ahu je možné nájst' očakávane v rozdielnosti domicilov strán, avšak špecifikum naviazania daného typu zmlúv na právo duševného vlastníctva „umožňuje“ vznik medzinárodného prvku aj v súvislosti s patentovaním práva $\mathrm{v}$ inom štáte alebo dopadom účinkov zmluvného záväzku v inom štáte. ${ }^{11}$ Po určení existencie relevantného medzinárodného prvku, ${ }^{12}$ musí národný ( $\mathrm{v}$ našom prípade český) súd následne pristúpit’ k výberu normy dopadajúcej na daný spor (samozrejme okrem procesných otázok). Súd preto skúma, ktorý relevantný právny prameň sa použije na daný spor. ${ }^{13} \mathrm{Aj}$ napriek tomu, že pred relatívne krátkym časom uzrel svetlo sveta ZMPS, vo svojom znení uvádza výslovný odkaz na európske normy v prípade záväzkového práva (Nariadenie Rím I, Nariadenie Rím II). ${ }^{14} \mathrm{~V}$ tejto oblasti nenastala žiadna významná zmena oproti starej úprave, kedy spory z licenčnej zmluvy boli podriad'ované pod všeobecné kolízne pravidlo. ${ }^{15}$

7 PAUKNEROVÁ, Monika. Prameny mezinárodního práva soukromého v České republice. In: KUČERA, Zdeněk, PAUKNEROVÁ, Monika, RƯŽIČKA, Květoslav a kol. Mezinárodní právo soukromé. 8. vyd., Plzeň: Vydavatelství a nakladatelství Aleš Čeněk, 2015, s. 58-61.

8 ROZEHNALOVÁ, Naděžda. Nařízení Řím I-základ unifikace závazků ze smluv. In: ROZEHNALOVÁ, Naděžda, VALDHANS, Jiří, DRLIČKOVÁ, Klára, KYSELOVSKÁ, Tereza. Meżinárodní právo soukromé Evropské unie: (Nař̃zení Rím I, Nařzeneni Rím II, Nař̌zení Brusel I). Praha: Wolters Kluwer Česká republika, 2013, s. 64-70.

9 Zákon 91/2012 Sb., o mezinárodním právu soukromém, ve znění pozdějších předpisů. In: ASPI [právny informačný systém]. Wolters Kluwer ČR [cit. 20. 8. 2016].

10 Nariadenie Európskeho Parlamentu a Rady (ES) č. 864/2007 z 11. júla 2007 o rozhodnom práve pre mimozmluvné záväzky (RÍM II). In: EUR-Lex [právny informačný systém]. Úrad pre vydávanie publikácií Európskej únie [cit. 20. 8. 2016].

11 KUNZ, Otto. Vynálezyy v mezinárodním právu. Praha, Academia, 1966, s. 209-210.

12 PAUKNEROVÁ, Monika. Pojem a předmět mezinárodního práva soukromého. In: KUČERA, Z., PAUKNEROVÁ, M., RŮŽIČKA, K. a kol., op. cit., s. 23-24.

13 ROZEHNALOVÁ, Naděžda. Evropský justiční prostor ve věcech civilních. In: ROZEHNALOVÁ, N., VALDHANS, J., DRLIČKOVÁ, K., KYSELOVSKÁ, T., op. cit., s. 16-17.

$14 \int 87$ ZMPS.

15 TELEC, 2002, op. cit., s. 167. 


\section{Prednostné použitie medzinárodnej zmluvy}

Na úvod je potrebné vysporiadat' sa primárne s otázkou existencie prameňov, ktoré sú v hierarchii vyššie ako Nariadenie Rím I, ako prameňa dopadajúceho na medzinárodnú licenčnú zmluvu. Existuje vel'ké množstvo medzinárodných zmlúv zameraných na právo duševného vlastníctva. Avšak pre účely tohto článku nie sú relevantné, ked’že neobsahujú kolíznu úpravu. ${ }^{16}$

Okrem mnohostranných medzinárodných zmlúv existujú pochopitel'ne aj bilaterálne, ktoré aj napriek existencii Nariadenia Rím I majú svoju dôležitost’. Bilaterálne zmluvy, na rozdiel od medzinárodných zmlúv o právach duševného vlastníctva, už často obsahujú kolízne normy. Dôležitý je konflikt prameňov v prípade nepoužitia Nariadenia Rím I. Ak jedna zo strán má bydlisko mimo územia Európskej únie a zároveň existuje medzinárodná zmluva, v tomto prípade bilaterálna, ktorá upravuje záväzkové vzt’ahy, má prednost' pred Nariadením Rím I. ${ }^{17}$ Licenčná zmluva z tohto záveru nemá dôvod byt' vylúčená, preto aj v jej prípade relevantná bilaterálna zmluva môže mat' prednost' pred Nariadením Rím I.

Relevantné zmluvy v tejto oblasti existujú. V prípade Českej republiky sa bude primárne jednat' o bilaterálne zmluvy s krajinami kedysi patriacimi do ZSSR alebo Juhoslovanskej republiky či krajiny úplne mimo Európy. ${ }^{18}$ Ked' nahliadneme do znenia niektorých bilaterálnych zmlúv o právnej pomoci, ${ }^{19}$ nájdeme viaceré kolízne opatrenia zameriavajúce sa na rodinné, trestné a civilné spory. Z vyššie spomenutého môžeme licenčnú zmluvu podriadit’ jedine pod civilné otázky. Bilaterálne zmluvy upravujú v civilných sporoch len oblasti, ktoré sú vysoko citlivé a silno späté s daným štátom (svojprávnost', prehlásenie

16 KYSELOVSKÁ, Tereza. Intellectual property rights. In: ROZEHNALOVÁ, Naděžda, DRLIČKOVÁ, Klára a kol. Czech private international law. Brno: Masarykova univerzita, Právnická fakulta, 2015, s. 192-202. Pre bližśí zoznam pozri International Treaties and Conventions on Intellectual Property (online). World Intellectual Property Organization [cit. 20. 8. 2016]. Dostupné z: http://www.wipo.int/export/ sites/www/about-ip/en/iprm/pdf/ch5.pdf

17 PAUKNEROVÁ, Monika. Prameny mezinárodního práva soukromého v České republice. In: KUČERA, Z., PAUKNEROVÁ, M., RŮŽIČKA, K. a kol., op. cit., s. 58-61.

18 Pozri zoznam bilaterálnych zmlúv v BELLOÑOVÁ, Pavla. Př́loha 2. Přehled dvoustranných mezinárodních smluv o právní pomoci, konzulárních úmluv a souvisejících prohlášení a sdělení. In: PAUKNEROVÁ, Monika, ROZEHNALOVÁ, Naděžda, ZAVADILOVÁ, Marta a kol. Zákon o meżinárodním právu soukromém: komentár. Praha: Wolters Kluwer, 2013, s. 828-841.

19 Pozri Vyhláška č. 207/1964 Sb. o Smlouvě mezi Československou socialistickou republikou a Socialistickou federativní republikou Jugoslávií o úpravě právních vztahů ve věcech občanských, rodinných a trestních. In: ASPI [právny informačný systém]. Wolters Kluwer ČR [cit. 20. 8. 2016]; alebo Vyhláška č. 95/1983 Sb. o Smlouvě mezi Československou socialistickou republikou a Svazem sovětských socialistických republik o právní pomoci a právních vztazích ve věcech občanských, rodinných a trestních. In: ASPI [právny informačný systém]. Wolters Kluwer ČR [cit. 20. 8. 2016]. Pre overenie, ktorý štát je viazaný vyššie uvedenými zmluvami pozri Vyhledávaní smluv. Ministerstvo zahraničních vécí České republikey. (online) Ministerstvo zahraničních věci České republiky [cit. 20. 8. 2016]. Dostupné z: http://www.mzv. cz/jnp/cz/vyhledavani_smluv/index\$45924.html 
za mŕtveho a iné) a v minimálnom prípade otázku formy právneho jednania. ${ }^{20}$ Samotnú kolíznu úpravu záväzkových vzt’ahov ponechávajú na úprave jednotlivých štátov.

$\mathrm{Na}$ základe vyššie uvedených tvrdení môžeme konštatovat’, že bilaterálne zmluvy s tretími štátmi majú prednost’ pred Nariadením Rím I a ZMPS, avšak neobsahujú kolíznu úpravu záväzkových vzt'ahov, ktorá by dopadala na licenčné zmluvy a preto ich nie je možné aplikovat' na spory vychádzajúce z licenčných zmlúv. Neostáva tak nič iné, ako následne aj v prípadoch, kedy je jedna zo strán z tretieho štátu s existujúcou bilaterálnou zmluvou, použit’ Nariadenie Rím I ako normu univerzálneho charakteru.

\section{Modelový spôsob použitia Nariadenia Rím I na licenčnú zmluvu}

Druhá oblast', okrem možnej prednosti bilaterálnej zmluvy, ktorá by mohla viest' k existencii prípadov vedúcich $\mathrm{k}$ použitiu iných prameňov ako Nariadenia Rím I vychádza z kombinácie medzier Nariadenia Rím I, vecnej pôsobnosti a kvalifikácie predmetu sporu. Ešte pred tým, než budú skúmané hranice použitia Nariadenia Rím I, je potrebné aspoň informatívne uviest' spôsob jeho použitia na licenčnú zmluvu. Postup pre určenie rozhodného práva pre spor vyplývajúci z medzinárodnej licenčnej zmluvy v rámci $\mathrm{Na}$ riadenia Rím I sa nijako neodlišuje od iných typov zmlúv. Prvým je uprednostnenie autonómie vôle strán (čl. 3). ${ }^{21} \mathrm{~V}$ prípade, že si strany právo nezvolili, nastupuje čl. 4, ktorý neobsahuje konkrétne kolízne pravidlo pre licenčnú zmluvu, preto je potrebné pristúpit' k náhradným krokom. Klúčovým pre určenie rozhodného práva sa stáva ustanovenie čl. 4 odst. 2, ktoré v prípade nepoužitia predchádzajúcich pravidiel používa hraničný určovatel’ určenia domicilu strany poskytujúcej charakteristické plnenie. ${ }^{22}$ Článok 4 odst. 4 Nariadenia Rím I používa hraničný určovatel' najužšieho spojenia, toto pravidlo sa však použije iba pri nemožnosti použitia predchádzajúcich pravidiel uvedených v prvom a druhom odstavci. ${ }^{23}$ Celú situáciu uzatvára tzv. úniková doložka umožňujúca použitie hraničného určovatel’a najužšieho spojenia. ${ }^{24,25}$

20 Porovnaj čl. 18-45 Smlouvy mezi Československou socialistickou republikou a Socialistickou federativní republikou Jugoslávií o úpravě právních vztahů ve věcech občanských, rodinných a trestních.; a čl. 18-48 Smlouvy mezi Československou socialistickou republikou a Svazem sovětských socialistických republik o právní pomoci a právních vztazích ve věcech občanských, rodinných a trestních.

21 ROZEHNALOVÁ, Naděžda. Nařízení Řím I-základ unifikace závazků ze smluv. In: ROZEHNALOVÁ, N., VALDHANS, J., DRLIČKOVÁ, K., KYSELOVSKÁ, T., op. cit., s. 85.

22 NISHITANI, Yuko. Contracts concerning intelectual property rights. In: FERRARI, Franco, LEIBLE, Stefan. (eds.). Rome I regulation: The Law Applicable to Contractual Obligations in Europe. Munich: Sellier. European Law Publishers, 2009, s. 55-59.

23 ROZEHNALOVÁ, Naděžda. Nařízení Řím I-základ unifikace závazků ze smluv. In: ROZEHNALOVÁ, N., VALDHANS, J., DRLIČKOVÁ, K., KYSELOVSKÁ, T., op. cit., s. 114.

24 Čl. 4 odst. 3. Nariadenia Rím I.; pozri NISHITANI, op. cit., s. 67-70.

25 Pre medzinárodnú licenčnú zmluvu sa stalo kl’účovým práve určenie, ktorá strana poskytuje charakteristické plnenie a zároveň, čo presne v prípade licenčnej zmluvy charakteristickým plnením je. Pozri NISHITANI, op. cit., s. 65-70. MANKOWSKI, op. cit.; s. 51-55.; DE MIGUEL ASENSIO, op. cit., s. 325-328. 
Ak je spor kvalifikovaný ako spor vychádzajúci z medzinárodnej zmluvy, to znamená dvojstranného zmluvného záväzku, je použitie Nariadenia Rím I pomerne jednoznačné. Nasledujúca kapitola hladá situácie, kedy jeho použitie už jednoznačné nie je.

\section{Vylúčenie použitia Nariadenia Rím I}

Existuje situácia za ktorej by bolo možné použit' aj v záväzkových otázkach ZMPS? Určite áno, avšak je pomerne výnimočná. ${ }^{26}$ Ked’že taká situácia ale môže nastat', dáva priestor na prípadne skúmanie použitia ZMPS na licenčnú zmluvu. Môžeme skúmat' otázku, v akej oblasti sa nepoužije Nariadenie Rím I aj napriek prepojeniu na licenčnú zmluvu.

Medzi potencionálne oblasti patrí existencia mimozmluvného záväzku spadajúceho pod Nariadenie Rím II, licencia kvalifikovaná ako jednostranné právne jednanie a s tým súvisiaca prevoditel'nost' práv.

\subsection{Kvalifikácia a interpretácia ako nástroje nepoužitia Nariadenia Rím I}

Hlavným nástrojom skúmania limitov použitia Nariadenia Rím I na medzinárodnú licenciu je jej kvalifikácia. Kvalifikácia umožňuje: „př̌pad právně hodnotit, kevalifikovat, aby jej bylo možno podradit (subsumovat) pod nèkterý z. právnich pojmů obsažených v rozsahu koliznich norem “27 Najskôr musíme skutkový stav vyhodnotit' a následne hl'adat' kolíznu normu, ktorú podrobíme interpretácii. ${ }^{28}$ Inak tomu nie je ani v prípade sporu vyplývajúceho z medzinárodnej licenčnej zmluvy.

Ak chceme zistit’, či daný spor spadá alebo nespadá pod Nariadenie Rím I, je potrebné ho kvalifikovat'. Kvalifikácia únijného predpisu, označovaná aj ako autonómna, nemá odkazovat' na lex fori a iné. ${ }^{29}$

Ďalším styčným bodom je interpretácia, ktorá je kl’účová pre nájdenie správnej kolíznej normy, ${ }^{30}$ či už vo vnútroštátnom, európskom alebo medzinárodnom prameni. Ako bude evidentné v nasledujúcich podkapitolách, kvalifikácia je určujúcim faktorom v procese skúmania.

26 BŘÍZA, Petr. Nový český zákon o mezinárodním právu soukromém v kontextu práva EU a mezinárodních smluv. Prární roz̧bledy. 2013, roč. 21, č. 17, s. 584.

27 PAUKNEROVÁ, Monika. Kvalifikační problém. In: KUČERA, Z., PAUKNEROVÁ, M., RƯŽIČKA, K. a kol., op. cit., s. 137.

28 ROZEHNALOVÁ, Naděžda. \20 Kvalifikace. In: PAUKNEROVÁ, M.; ROZEHNALOVÁ, N.; ZAVADILOVÁ, M., op. cit., s. 143.

29 Ibid, s. 146-147.

30 PAUKNEROVÁ, Monika. Kvalifikační problém. In: KUČERA, Z., PAUKNEROVÁ, M., RU゚ŽIČKA, K. a kol., op. cit., s. 152-153. 


\subsection{Mimozmluvný záväzok ako súčast' medzinárodnej licencie spadajúci pod Nariadenie Rím II}

Prvú vylúčenú oblast' nám pomôže identifikovat' vyššie spomenutá kvalifikácia. Základným vymedzením vecnej pôsobnosti Nariadenia Rím I vyplývajúcim už z názvu je zameranie na zmluvné záväzky. ${ }^{31}$ Automaticky preto vypadáva z použitia Nariadenia Rím I všetko, čo nie je zmluvným záväzkom. V práve duševného vlastníctva sem patria otázky vzniku práva duševného vlastníctva, porušenia alebo jeho obsahu. ${ }^{32}$ Tieto oblasti tak následne spadajú pod klasický hraničný určovatel’ lex loci protectionis, nachádzajúci sa v úprave Nariadenia Rím II alebo iné normy dopadajúce na danú oblast', ${ }^{33} \mathrm{v}$ tomto prípade hraničný určovatel' lex loci protectionis v ZMPS. ${ }^{34}$ Hraničný určovatel' lex loci protectionis je východiskovým nástrojom určovania rozhodného práva. Opiera sa o zásadu teritoriality, ktorá hrá stále významnú úlohu v práve duševného vlastníctva a preto ovplyvňuje aj možný výber rozhodného práva. ${ }^{35}$

V prípade licenčných zmlúv je preto spornú otázku napríklad prevoditel'nosti práva, či už patentu alebo autorského práva, potrebné kvalifikovat' či už ako zmluvný záväzok, mimozmluvný záväzok alebo oblast' nespadajúcu ani pod jednu z týchto kategórii, a to následne ovplyvní výber správnej normy. ${ }^{36} \mathrm{Ak}$ by spor spočíval prevažne v porušení práva duševného vlastníctva, tak by sa primárne použilo Nariadenie Rím II. Avšak otázky ako existencia, platnost' práva budú podliehat' už národným kolíznym normám. ${ }^{37}$

Aj v prípade odklonu od Nariadenia Rím I či Rím II pre strany sporu nenastáva prekvapenie v prípade použitia iného alebo neznámeho hraničného určovatel’a. Česká kolízna úprava sa neodlišuje od všeobecne uznávaných princípov v oblasti práva duševného vlastníctva.

Dochádza k tzv. mozaikovej úprave, ktorú je preto oblasti práva duševného vlastníctva možné očakávat'. ${ }^{38}$

31 Preambula Nariadenia Rím I.

32 MCPARLAND, Michael. The Rome I regulation on the law applicable to contractual obligations. Oxford: Oxford University Press, 2015, s. 187-190.

33 VALDHANS, Jiří. Pránni úprava mimosmluvnich závazłki s mezinárodním prvkem. Praha: C. H. Beck, 2012, s. 200-202.

$34 \int 80$ ZMPS.

35 BASEDOW, Jürgen. Foundations of Private International Law in Intellectual Property. In: BASEDOW, Jürgen, KONO, Toshiyuki, METZGER, Axel. (eds.). Intellectual Property in the Global Arena. Tübingen,:Mohr Siebeck, 2010, s. 12-14, 29; POLÁČEK, Bohumil. \ 80 Právo duševního vlastníctví. In: PAUKNEROVÁ, M., ROZEHNALOVÁ, N., ZAVADILOVÁ, M. a kol., op. cit., s, 523; TŮMA, Pavel. Smluvni licence v autorském právu. Praha: C. H. Beck, 2007, s. 136-137.

36 DE MIGUEL ASENSIO, op. cit., s. 312-316.

37 KONO, Toshiyuki, JURČYS, Paulius. General report. In: KONO, Toshiyuki (ed.). Intellectual property and private international law: comparative perspectives. Oxford: Hart publishing, 2012, s. 138-139; DE MIGUEL ASENSIO, op. cit., s. 314, poznámka pod čiarou č. 4.

38 VALDHANS, op. cit., s. 200; DE MIGUEL ASENSIO, op. cit., s. 315. 


\subsection{Jednostranné právne jednanie spadajúce pod ZMPS a prevoditel’nost' práv}

Ďalšiu možnú oblast' opät' vytvára kvalifikácia. Na základe kvalifikácie určitého aspektu licenčnej zmluvy ako jednostranného záväzku namiesto dvojstranného vylúčime použitie Nariadenia Rím I.

Príkladom vylúčenej otázky z vecnej pôsobnosti Nariadenia Rím I je jednostranné právne jednanie. Problematika hl'adania kolíznej normy dopadajúcej na jednostranné právne jednanie spadá pod ZMPS. ${ }^{39}$ Ak kvalifikácia určila daný predmet sporu ako spor vyplývajúci z jednostranného právneho jednania, nepoužije sa Nariadenie Rím I. Ked’ následne vylúčime použitie Nariadenia Rím I a zvažujeme použitie ZMPS, musíme poukázat' na fakt, že nový zákon už výslovne upravuje kvalifikáciu a na prvom mieste uprednostňuje kvalifikáciu lex fori. ${ }^{40}$

Pre úplnost' je potrebné dodat', že sa nejedná o prípady jednostranného právneho jednania nadväzujúceho na dvojstrannú zmluvu, ktoré by taktiež spadali pod Nariadenie Rím I. ${ }^{41}$

Ak sa snažíme nájst’ prípad, kedy by spor z licenčnej zmluvy v praxi mohol aspoň potencionálne vyvolávat' otázky použitel’nosti Nariadenia Rím I, vyššie uvedené spĺn̆a primárne autorské právo a otázka možnosti či nemožnosti autora určitý druh svojich práv previest' na inú osobu ${ }^{42}$ a zároveň právo autora dat' súhlas k využívaniu jeho diela. ${ }^{43}$

Príkladom situácie, kedy sa licencia nemusí vnímat’ ako jednoznačne dvojstranný záväzok, nám ponúka české vnútroštátne právo, ktoré síce nie je relevantné pre kolízne normy, ale ako predpoklad kvalifikácie lex fori je vhodné.

Ako zaujímavo upozorňuje Telec, v prípade autorského práva hrá významnú úlohu tzv. súhlas (jednostranne právne jednanie), ktorý nevytvára záväzok medzi dvoma stranami. Autor jednoducho jednostranne udel’uje súhlas k využitiu diela (daný inštitút sa využíva pri verejných licenciách).$^{44}$ Práve táto skutočnost' vedie k úvahe, že nie všetko, čo sa na prvý pohl'ad javí ako dvojstranný záväzok, bude aj po kvalifikácii stále vnímané ako zmluvný záväzok dvoch strán spadajúci pod Nariadenie Rím I a preto sa otvára možnost' použitia ZMPS.

V prípade jednostranného právneho jednania zákon obsahuje v \90 ZMPS hraničný určovatel' obvyklého pobytu osoby, ktorá toto jednanie učinila. Ked’že autorské právo

39 BŘíZA, 2013, op. cit., s. 586.

$40 \rrbracket 20$ ZMPS.

41 MCPARLAND, op. cit., s. 187.

42 DE MIGUEL ASENSIO, op. cit., s. 316-317.

43 TELEC, Ivo. Souhlas nebo Licenční závazek. Právní roz̧bledy. 2013, roč. 21, č. 13/14, s. 460-461.

44 TELEC, 2013, op.cit., s. 460-462. Táto problematika je podrobená akademickej debate - pozri taktiež MYŠKA, Matěj. Veréjné licence. Brno: Masarykova univerzita, 2014, s. 127-128; TELEC, Ivo. Právo duševníbo vlastnictví v informační společnosti. Praha: Leges, 2015, s. 187, poznámka pod čiarou č. 186. 
je silne prepojené na teritórium, je možné predpokladat' jednotnost' takto určeného rozhodného práva s lex loci protectionis. V čom môže spočívat' problém použitia $\int 90 \mathrm{v}$ tejto situácii je považovanie jednostranného právneho jednania $\mathrm{v}$ podobe licencie za nezáväzkové právne jednanie, ${ }^{45}$ pričom autori sa zhodujú, že $\int 90$ je zameraný na záväzkové právne pomery. ${ }^{46}$ Zároveň ustanovenie $\int 90$ bolo cielené na jednostranné právne jednania typu verejná sút'až alebo sl'ub odškodnenia, ${ }^{47}$ od ktorých sa takáto podoba licencie odlišuje.

Okrem toho, prísnym použitím vyššie uvedenej úvahy a následne aplikácie $\int 90$ sa v realite dostávame do labyrintu kolíznych noriem, ktorý rozhodne neposkytuje predvídatel'nost' a právnu istotu.

Preto v praxi aj napriek tomu, že by azda bolo možné určitý prejav vo forme licencie kvalifikovat' ako jednostranné právne jednanie, predpokladaným d'alším postupom bude podriadenie sporu pod $\int 80$ a následná aplikácia lex loci protectionis.

S touto úvahou súvisí analýza, či vôbec je možné licenciu takýmto spôsobom poskytnút'. Spor o tom, že autor môže takéto jednostranné právne jednanie uskutočnit', je vlastne otázka prevoditel'nosti autorského práva, obsahu a limitov majitel’a práva a či vôbec právo umožňuje takýto vznik licencie. ${ }^{48}$

Je sporné právo prevoditel'né a do akej miery? $\mathrm{V}$ prípade autorského práva je úprava prísnejšia ako v prípade napr. patentov a výrazne sa preferuje podriadenie otázky prevoditel'nosti práv (čo je prevoditel'né, obsah práv, za akých podmienok) pod lex loci protectionis. $^{49}$

\section{Záver}

Ciel’om článku bolo nájst' situácie, ktoré by vyžadovali použitie iného právneho prameňa ako Nariadenia Rím I v sporoch vyplývajúcich z licenčných zmlúv. Otázka, či je možné odklonit' sa od použitia Nariadenia Rím I pri problematike licenčných zmlúv, súvisí so samotnou kvalifikáciou predmetu sporu. Ak český súd kvalifikuje záväzok ako dvojstranný, je použitie Nariadenia Rím I jednoznačné. V tomto prípade mohla výnimku predstavovat' prednost' použitia bilaterálnych zmlúv uzavretých s nečlenskými štátmi Európskej únie, ktoré by obsahovali vhodnú kolíznu úpravu. Tie však neexistujú.

45 TELEC, 2015, op. cit., s. 204.

46 ROZEHNALOVÁ, Naděžda. \ 90 Jednostranná právní jednání. In: PAUKNEROVÁ, M., ROZEHNALOVÁ, N., ZAVADILOVÁ, M., op. cit., s. 620; BŘÍZA, Petr \90. In: BŘÍZA, Petr, BŘICHÁČEK, Tomáš, FIŠEROVÁ, Zuzana a kol. Zákon o mezinárodním právu soukromém: komentár. Praha: C. H. Beck, 2014, s. 550.

47 PFEIFFER, Magdalena. Závazkové právo. In: KUČERA, Z., PAUKNEROVÁ, M., RŮŽIČKA, K. a kol., op. cit., s. 303.

48 DE MIGUEL ASENSIO, op. cit., s. 316-318; KONO, JURČYS, op. cit., s 135.

49 DE MIGUEL ASENSIO, op. cit., s. 316-317. 
Ak spornú čast' licencie súd považuje za čast’ práva duševného vlastníctva ako takého, jednoznačne sa presúvame $\mathrm{k}$ lex loci protectionis, či už v prípade porušenia práva $\mathrm{k}$ Nariadeniu Rím II alebo v iných otázkach (vznik práva, vlastníctvo) k ZMPS.

Ako bolo uvedené vyššie, spojenie „medzinárodná licencia“ nemusí vždy predstavovat' iba označenie dvojstranného záväzku a preto je potrebné postupovat’ pozorne pri jeho kvalifikácii. Týmto spôsobom by bolo možné $\mathrm{v}$ určitých vel'mi špecifických situáciách pristúpit' $\mathrm{k}$ použitiu ZMPS a hraničného určovatel'a lex loxi protectionis. Ak by aj v prípade licenčnej zmluvy viedla kvalifikácia $\mathrm{k}$ použitiu iného paragrafu ako $\ 80$, v rámci zachovania právnej istoty a všeobecne podporovaného princípu lex loci protectionis sa prikláňame v prípade nejasných otázok, ktoré sú jasne kvalifikované ako nezmluvné, $\mathrm{k}$ aplikácii hraničného určovatel'a lex loci protectionis.

Na záver je možné konštatovat', že dvojstranný zmluvný licenčný záväzok spadá pod Nariadenie Rím I a situácie, ktoré by viedli k použitiu iného prameňa pri jednoznačne kvalifikovanom dvojstrannom záväzku, sú výnimočné. 